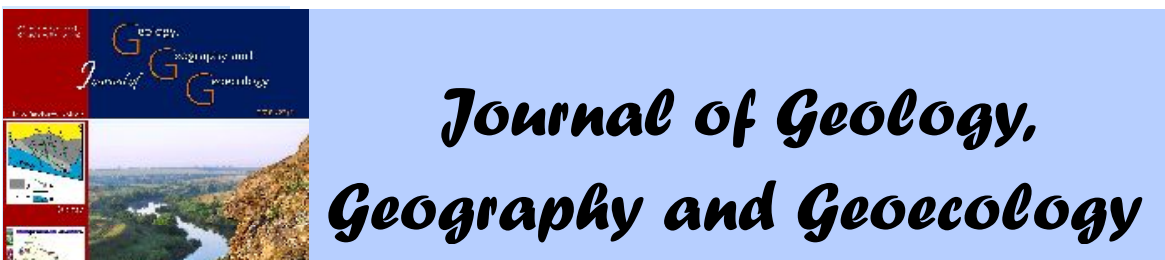

Journal home page: geology-dnu-dp.ua

Journ.Geol.Geograph.

Geoecology,

27(1), 148-155

doi: $10.15421 / 111840$

Yavorska V. V., Hevko I. V., Sych V. A., Kolomiyets K. V.

Journ.Geol.Geograph.Geoecology,27(1), 148-155

\title{
The main components of the formation of recreational and tourism activity
}

\author{
V. V. Yavorska ${ }^{1}$, I. V. Hevko ${ }^{2}$, V. A. Sych ${ }^{1}$, K. V. Kolomiyets ${ }^{1}$

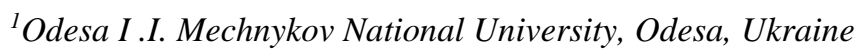 \\ ${ }^{2}$ Ternopil Volodymyr Hnatiuk National Pedagogical University
}

Received 22.04.2018;

Received in revised form 18.05.2018;

Accepted 30.05.2018

Abstract. The article considers the issues of further development of the conceptual apparatus of such a direction as recreation and tourism and the question of determining the various directions and components of recreation and tourism economy. The purpose of this work is to identify the main components of recreational and tourist activity as an integral part of the inter-sectoral complex. It is stressed that tourism activity can be viewed from the standpoint of the economy, because it has all the features of the economy, although this approach is not widespread. It is also possible to study the recreation and tourism sector as a type of economic activity. Recreational and tourist activity is considered as a service market, both as a social system and as an economic system. It was emphasized that in geography and regional economy, recreational and tourist activity is considered as an inter-sectoral complex. A pivotal problem is the definition of objects and entities in systemic relations, where, depending on the nature of the system, tourists can act as objects and subjects. It was established that the formation of the subject area of recreational and tourist activity is based on geographical concepts, including the concept of «tourist destination», the concept of territorial organization of the population and economy, the concept of territorial recreational systems. The position of geographers in the development of the subject area of tourism enhances resource orientation of tourism activity; we note that the resource is both population and tourist destinations. In the article we considered the Ukrainian taxonomy of types of economic activities, which are directly involved in tourism and recreation. It is determined that tourism and recreation sector occupy a special place in the sphere of services. In essence, tourist services are multi-component, and the tourist product itself combines the result of the activities of enterprises that carry out completely different activities. The schematically structured recreation and tourism complex by types of activities indicates the formation of areas of economic activity and industry directly related to recreation and tourism, such as mass recreation of the population - unorganized and organized, and tourism, the sphere of recreation. Thus, the representation of recreation and tourism activity as an inter-branch complex offers new possibilities for forecasting its development and formation of new directions of use of recreational and tourist resources.

Key words: recreation, tourists' activity, destination, recreational and tourist resources, geographical principles, inter-sectoral complex

\section{сновні компоненти формув ння рекре ційно-туристичної діяльності}

. . ворськ ${ }^{1}$, . евко $^{2}$, . ич $^{1}$, . оломієць $^{1}$

1 деський н ціон льний університет імені . . ечников

2 ернопільський н ціон льний пед гогічний університет імені олодимир н тюк

нот ція. озглянуто пит ння под льшого розроблення понятійно - концепту льного п р ту т кого н пряму діяльності як рекре ційно - туристичн т пит ння визн чення різних н прямів т компонентів рекре ційно-туристичного господ рств .

голошено, що туристичну діяльність можн розгляд ти з позицій г лузі господ рств, оскільки вон м є всі озн ки г лузі економіки, хоч т кий підхід не поширений. ідкреслено, що в геогр фії т регіон льній економіці рекре ційно - туристичну діяльність розгляд ють як міжг лузевий комплекс. озглянуто систем тику видів економічної діяльності, які безпосередньо 3 діяні в туризмі т рекре ції, т н ведено структурув ння рекре ційно -туристичного комплексу з вид ми діяльності. екpe ційно - туристичн діяльність розгляд ється і як ринок послуг, і як соці льн систем , і як економічн систем . трижнев проблем поляг є у визн ченні об'єктів т суб'єктів у системних відношеннях, де 3 лежно від х р ктеру системи туристи можуть виступ ти як суб'єкт ми, т к і об'єкт ми. ст новлено, що формув ння предметної г лузі рекре ційно - туристичної діяльності б зується н геогр фічних концепціях, серед яких концепція «туристичної дестин ції», концепція територі льної орг ніз ції н селення і господ рств , концепція територі льних рекре ційних систем.

лючові слов : рекре ція, туристичн діяльність, дестин цї, рекре ційно-туристичні ресурси, геогр фічні принципи, міжг лузевий комплекс 
Introduction. Quite quickly, though completely unobtrusively for the eye, tourist trips, which were originally available only to selected ones, have become one of the main engines of the world economy. «Hunting for the change of places» was characteristic of mankind from the very beginning of its existence, but only in the last century, this need was transformed into a commercial product. In the 60's of the twentieth century, due to cheaper flights and the expansion of package tours, humanity has reopened the world itself - the so-called «tourist revolution» or «revolution of services» took place. For example, in 2017, tourism totaled 7.6 trillion. dollars of global economic activity - a little more than one tenth of the GDP of the planet, and the number of travelers steadily increasing and to date is 1.25 billion people a year (The Travel \& Tourism, 2017).

Thereby the rapid development of tourism have led to increased attention to recreational and tourist activities and its in-depth theoretical and methodological development. The situation is complicated by the interdisciplinary nature of this scientific direction and the increasing competition of various sciences in its development.

A significant number of scientific publications, ideas, concepts are dedicated to the various aspects of recreational and tourist activity from the standpoint of consideration in social geography. Such Ukrainian geographers as O. Beidyk, O. Lyubitseva, O. Kolotukha, O. Shabliy, I. Smal, I. Smirnov, O. Topchiyev, F. Zastavniy, and others have devoted theirs papers to the issue of tourist activity of the country in whole and different regions. At the same time, insufficient attention is paid to the issue of geographical principles of recreational and tourist activity as a branch of national economy.

The purpose of this work is to identify the main components of recreational and tourist activity as an integral part of the inter-sectoral complex.

The researchers again and again emphasize the uniqueness of tourism in terms of the scale and pace of its dissemination, as well as its interdisciplinary multidimensional and substantive complexity. Tourism is viewed as a socio-economic phenomenon (Van Tsynshen, 2003, Oliynyk, Stepanenko, 2005, Maslyak, 2008, Tkachenko, 2009, Topchiyev, 2005), which in the second half of the twentieth century. gave birth to a tourist revolution comparable to the civilizational consequences of the industrial revolution. And in this context, it should be considered as one of the factors and stages of civilization advancement of mankind. In the field of tourism, the interests of economy and culture, regional studies and ethnography, natural history and history, ethnography, culture and sport, international relations and ties. Tourism combines the trends of globalization and ethno-national identity. Tourist activity comprehensively connects the spheres of material production, exchange, circulation, service, leisure and provides the features of completeness of economic complexes of all levels. Tourism is regarded as one of the priority sectors of the economy and as one of the most dynamic types of business (Tkachenko, 2009, Topchiyev, 2005).

Material and methods of the study. The materials of the research were literary sources, as well as some developments of modern ukrainian and foreign scientists on the study of recreation and tourism activities. The use of logical-analytical, comparative and descriptive methods, which enabled to highlight the peculiarities of the formation of the subject area of recreational and tourist activity, was important for achieving the goal.

Results of the study and their discussion. The problem of the formation and arrangement of conceptual apparatus of recreational and tourist activity is the most difficult one today. Among contemporary scholars, it is widely believed that "recreation" is a much broader concept, since it includes virtually all types of human activities in its free time, which is spent outside its permanent home, while "tourism" the concept is narrower and deeper, as this process is accompanied by the consumption of the relevant services, that is, the purchase of certain products / goods or services and the use of resource potential of the territory.

Concerning the notion of recreational activity, there are many definitions, in our opinion the most complete of the following: recreational activity - the activity of man in his spare time, carried out in order to restore the physical and spiritual forces of man and is characterized by a variety of human behavior and the value of its process (Velychko, 2013).

Tourist activity is considered as an industry or type of economic activity (Fig. 1) (Velychko, 2013, Dyachenko, 2007, Zoryn, Kvartal'nov, 2000, Oliynyk, Stepanenko, 2005). Modern tourism has all the necessary features of the economy, among which: - the demands of society for travel services;

- production of specific products - tours, tourist product;

- availability of tourists and goods manufacturers and their consumers;

- the use of special resources - destinations, technologies, organizational and economic forms;

- mass development of entrepreneurship;

- profit is a sign of economic activity.

This approach applies to all economics, partly to managers. But most of the researchers emphasize the very limited nature of tourism as an industry. 
Let us show some methodological conflicts of this approach. Tourist activity is represented as an economic system, which produces and exchanges tourist services and goods (Velychko, 2013, Dyachenko, 2007). The aggregate of enterprises and organizations of the sphere of services and sphere of material production, which provide production and distribution of tourist products and goods, development and exploitation of tourist resources, the formation of the infrastructural material and technical base of tourism, are called tourism industry. We emphasize that tourists is not marked in this system: they must necessarily be, but outside of the economic system.

In modern conditions, recreational and tourist activities are regarded as a market of services, in which tour operators and other actors form a recreational product and sell it to consumers - tourists. According to economic considerations, travel is a tourist product purchased by tourists, and on the basis of the object - subject relations in the field of travel services - is a specific activity of tourists themselves.

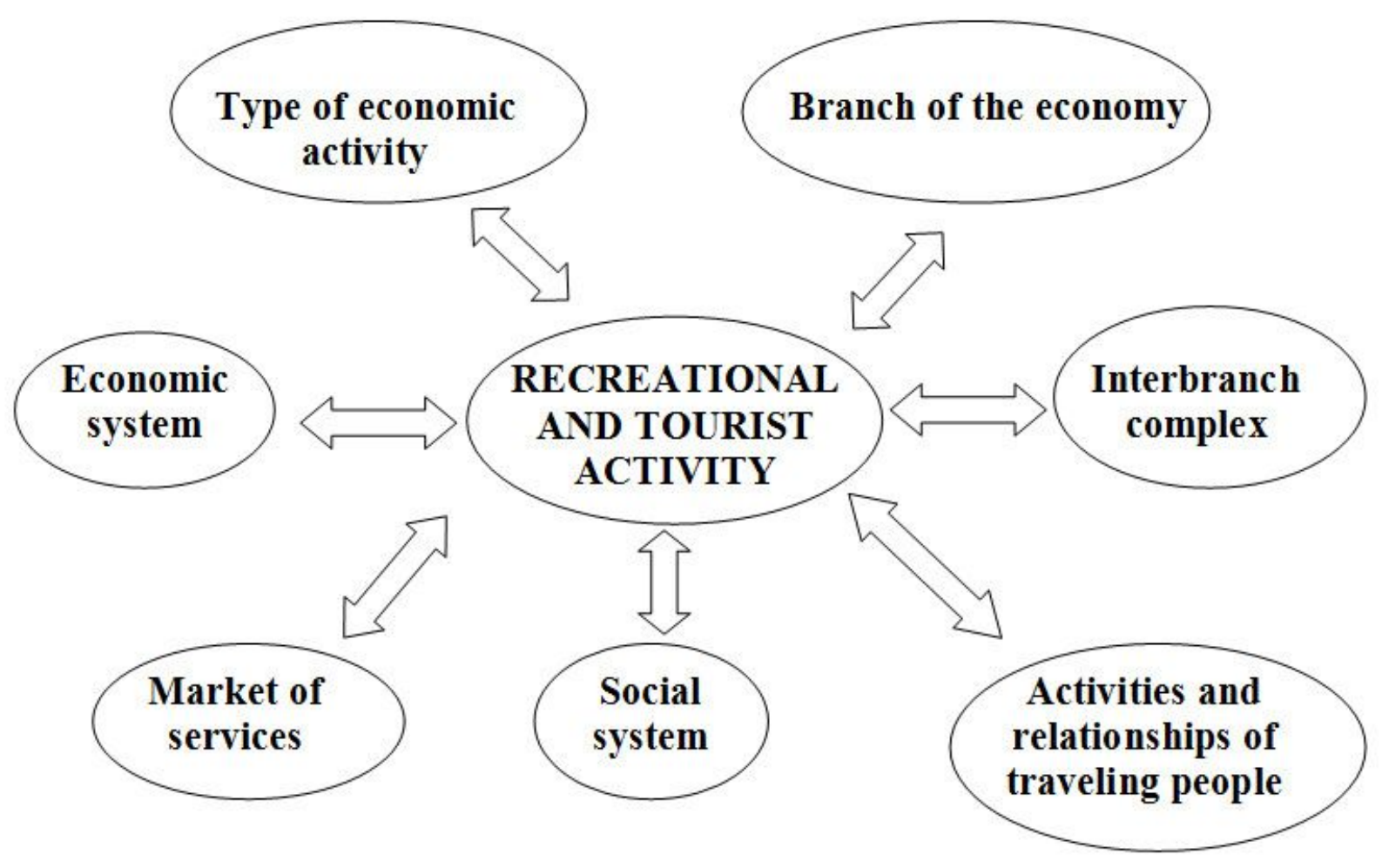

Fig. 1. Approaches to the definition of recreational and tourist activity

In some countries (for example, the Russian Federation), tourism has become officially defined as a type of economic activity (Zoryn, Kvartal'nov, 2000): tourism activity is tour operator and travel agency activities, as well as other activities for the organization of travel. This definition does not include tourists themselves and violates the logical meaning of «activity», which necessarily relates the subject of activity (tourists) with objects (tourist environment - destinations).

The widespread consideration of recreational and tourist activity as a social system, for which a complex methodological problem remains the subject - object relations. Consideration of tourism as a branch of the economy relies on the concept of an economic system, in which tourist enterprises (tour operators) - a subject of tourism activity, and tourists, consumers of tourism product - its object. At the same time, the representation of recreational and 150 tourist activities as a social system considers tourists as the subject of the system, and all other components - as its object. Note that according to the definition of the World Tourism Organization (UNWTO), subjects of tourism activity are tour operators, travel agents, tour guides, as well as tourist services - places of accommodation, cafes and restaurants. And here the paradoxical situation: tourist activity without tourists, tourism - without customers of tourist services. It is clear that all these developments and definitions already require further refinements and new approaches.

The State Agency of Ukraine for Tourism and Resorts, which operated until 2015, distinguished between tourism industries and recreational industries. The tourism industries (activities) include travel agencies and operators, excursion bureaus, sightseeing objects, objects and institutions of business purpose, collective accommodation facilities, 
covering hotels, hostels, motels, campsites, tourist bases and camps. Recreational activities are represented by collective recreation facilities - recreation centers, refreshment houses, as well as collective accommodation facilities for rehabilitation and treatment - sanatoria, health improvement clinics, refreshment houses with treatment, children's institutions of the whole year, children's centers, health institutions (of short- 2 days stay), balneological hospitals.

The structure of the recreational and tourist economy includes related industries, represented by enterprises of food and trade, transport and communal services, as well as corresponding establishments, institutions and organizations - specialized educational institutions, banking institutions, public organizations.

Despite the rather clear and complete list of objects of recreation and tourism activity, the relevant sector (branch) of economy in Ukraine continues to be formed at present. Today, the function of the central executives, which ensures the implementation of tourism policy, is carried out by the Department of Tourism and Resorts under the Ministry of Economic Development and Trade of Ukraine. In the regions administrations this direction is presented by separate departments and committees with very limited administrative powers.

The United Nations Statistical Commission has adopted a temporary classification of tourism activities (1993) - Standard International Classification of Tourism Activities (SICTA). There are 74 specialized types (subclasses) of economic activity, as well as 110 types, which are partly related to tourism, are classified into the sphere of tourist services. As you can see, numerous types of economic activity are directly included in the tourist services, or they can partially carry out tourist functions. There is a problem of determining the boundaries of tourism: where begins and where ends tourist activity.

Tourism covers most sectors of the economy: industry, agriculture, construction, transport, communications, trade, public catering, housing and communal services, consumer services, culture, arts, sports, science, credit and financial services and insurance, computer science. The changes taking place in recent decades in the global economy, (consolidation and massive displacement industries, strengthening of integration processes between countries and entire regions, globalization and regionalization) led to the formation and development of new highly differentiated inter-industry complexes rather than isolated branches of economy. In this sense, tourism and hospitality industry can be characterized as a single interdisciplinary complex consisting of various industry servicing tourists in order to satisfaction of tourist needs. At the same time, in the services sector, the tourist sector occupies a central position, due to the high complexity and close interconnections of tourist services within all sectors. So in the national economy, tourism is viewed both as a branch of the national economy and as an interbranch complex, although it is clear that these two approaches are opposed to each other.

The unified link in the national classification of economic activity types (CEAT-2010) is chapter 79 of the section $\mathrm{N}$-activities of travel agents, tour operators, provision of other reservation services, and related administrative and auxiliary services. Their list continues chapter 77 - rent, hire and leasing, chapter 81 - maintenance of houses and territories, chapter 82 - administrative and auxiliary office activities, other auxiliary commercial services.

One of the main target of recreational facilities is health and treatment, directly related to section $\mathrm{Q}$, chapter 86 - health care. For many types of recreation, the $\mathrm{R}$ section is a base and includes art, sports, entertainment and recreation, also its chapters: $90-$ activities in the field of creativity, art and entertainment, 91 - functioning of libraries, archives, museums and other cultural institutions, 92 - organizing gambling, 93 - activity in the field of sports, organization of rest and entertainments. A milestone for recreational activities is Section I - Temporary Accommodation and Catering, which has two chapters: 55 - Temporary Accommodation and 56 - Food and Drink Activities.

As we see, the latest national classification of economic activity types, which complements and partly replaces the traditional sector taxonomy, can not clearly determine the place of recreation and tourism as a type of economic activity. As in the industry classification, recreational and tourist activities cover a large number of classification units.

The complicated methodological problem is subject - object relations in recreational and tourist activity in general. Consideration of tourism as a branch of economy or kind of economic activity relies on economic systems in which tourism enterprises are the subject of tourism activity, and tourists, consumers of tourist product - its object. Representation of tourist and recreational activities as a social system considers tourists no longer as an object of the system, but as its subject. System forming attitudes to this approach are the «tourist actions» of travelers, their «tourist activity», their relation to the subsystem of the recreational and tourist economy, which is already the object of the system.

Gaining popularity approaches to the definition of tourism as the activities and relationships of people traveling. Contrary to the economic and industrial («tourism industry») definition of the subject of tourism in this direction tourists are the core of tourismology. According to such views, tourism 
is a phenomenon of universal culture, a means of self-realization of mankind. The main object of the researcher in this approach is «not hotels but people». The core of tourism science is «traveling man». It is believed that tourism is an integral part of mass culture of modern society, it corresponds to the main characteristics of the cultural forms of this phenomenon. Being its origin, tourism has in its basis the same principles of functioning as the mass culture. Having fun, a person satisfies his spiritual needs, evaluates his own personality, analyzes his role in the various social systems - this is the opinion of the supporters of mass culture. C. Mills, speaking of the self-consciousness of a modern man, wrote that he «tended to see himself as at least an alien, if not an eternal traveler, explaining this fact as a transforming force of history».

We emphasize the special role of the population in recreational and tourist activity: on the one hand, it is the subject of tourism and recreation, which forms the demand for tourist services and forms tourist flows; on the other hand, they are producers of tourist services and goods forming part of the «tourist industry». Population acts as a peculiar resource in relation to tourist and recreational activities. The recreational and tourist activity of the population is determined by equal welfare and quality of life, as well as its cultural and educational level and mentality.

Geographic science plays a special role in the formation of the subject area of recreational and tourist activity. General Secretary of the World Tourism Organization F. Franzialli (1997-2005) in a report at the International forum of the World Association of Professional Training in Hospitality and Tourism AMFORT (2000) emphasized that representatives of geographical science are most prepared to understand the essence of tourism. In tourism, the active interaction of society with nature is established (Franzialli, 2002). Therefore, tourism is defined as a form of natural - social life and life of a traveling person. Tourism is characterized as spatial (geographical) diverse human activity. One of the authoritative researchers $\mathrm{N}$. Leiper defines tourism as a holistic system that combines tourists, tourist attractions and tourism industry (Leiper, 1979).

Positions of geographers in the development of the tourism subject area enhances by he resource orientation of tourism activities. Tourism is a resource industry: the consumer value of a tourist product depends on the quality of recreational resources. The concept of rent for a recreational resource (J. Crampton, USA) is introduced as the difference between the income from the use of the available resource and the minimum income from the same resource that is used. As already noted, approaches to the definition of tourism as the relations of traveling people are becoming popular. In this approach, the population is a resource factor for tourism and its tourism activity is determined by the level of welfare and quality of life of the population, its mentality. And such characteristics - the prerogative of geographical disciplines in particular geography, regional geography.

Geographic science has made a significant contribution to the development of the category of recreational and tourist activities. Along with the traditional geographic and cadastral characteristics of natural conditions and natural resources for recreation purposes (Beydyk, 2001, Lyubitseva, Pankova, Stafiychuk, 2007, Fomenko, 2007), geographers have developed the concept of «tourist destination». Its author, N. Leiper (1970s), describes tourism as a spatial diverse human activity and emphasizes the activity principle as a major in the theory of tourism. $\mathrm{He}$ defines tourism as a holistic system that combines tourists, tourist destinations (objects, cities, regions) and the tourism industry. Such approach to the definition of the subject area of recreational and tourism activities called the activity direction (by Leiper). At present, the destinations are considered as the main component of tourist resources and as a nodal part of the tourism product.

Destinations are called territories attracting tourists and tourists, along with recreational natural resources, tourist attractions and routes included in the tourist product. In numerous tourist dictionaries, destinations are countries, regions, cities which attracting tourists and serving as the main centers of localization of tourism activity, flows of tourists and their outgoings. These are places of maximum concentration of tourist attractions and tourist facilities. Ukrainian researcher T. Tkachenko defines the destination as an object - a city, region, district, locality, place, institution that has tourist and recreational resources - unique or special, attractive for tourists, accessible due to the necessary infrastructure (amenities, services), brought to the consumer in the form of a well-developed and prepared for sale by modern means of marketing communications (logotype, trade mark, etc.) of a tourist product (Tkachenko, 2009). Modern researchers understand destinations most geographically and widely on such composition: 1) tourist resources; 2) tourism infrastructure; 3 ) tourist enterprises and organizations; 4) related enterprises for servicing tourists; 5) socio-economic environment; 6) the local population with its mentality.

Another compulsory geographical characteristic of recreational and tourist activity is its territorial organization. Geographers have developed the concept of territorial organization of the population and economy. Social geography is defined as a science of the territorial organization of society. For all types 
of economic activities, including for recreation and tourism, their placement and forms of territorial organization are investigated. At the local and regional levels, the concept of territorial recreational systems has already been developed (Van Tsynshen, 2003, Maslyak, 2008, Topchiyev, 2005). The concept of destinations, which brings together tourist attractions and regions, is gaining in popularity. At the global level, the features of international tourism, the formation of centers and regions of international tourism and the formation of tourist flows are explored.

In geography and regional economy, recreational and tourist activities are considered as an interbranch complex (Van Tsynshen, 2003, Topchiyev, 2005). On the one hand, recreation and tourism affect practically all sectors of the economy: industry, agriculture, transport and infrastructure, the social sphere in general, the sphere of service, social infrastructure, culture, education, science, management. On the other - in the economic complex formed the direction of economic activity and industry directly related to recreation and tourism, such as mass recreation of the population - unorganized and organized, and tourism.

Powerful sphere of domestic recreation of the population exists, which at present is not yet designated as a component of the economic complex and which, however, needs research, planning and management. Geographers traditionally call the recreation and tourism industry of the country or region a recreational (recreational and tourist) complex, emphasizing its interdisciplinary structure and character.

We analyze the recreational and tourist complex of the region (country) by types of recreation and tourism activity, as well as related constituents recreational and tourist resources, infrastructure, services (Fig. 2). Recreational and tourist activities satisfy the needs and demands of the population for recreation and tourism. It should be remembered that the needs of the population of other regions and countries (inbound tourism) can be satisfied also. Recreational activity is divided into short-term (domestic) and long-term, which can be unorganized (self-employed) - individual, family, mass, or organized (on a commercial basis). An integral part of the recreation is excursion activity, which can be covered with tourism (multi-day excursions). Tourist activities are divided into outbound and inbound (foreign tourists), as well as domestic (within its own country) and external (outbound).

In the recreational and tourist activities are involved infrastructure, which can be divided into two components: the general infrastructure serves the population entirely and directly tourist infrastructure, aimed at satisfiction the needs of tourists. The same division can be applied to the sphere of services and sphere of material production. Such a classification of tourist services has a methodological and methodological value for the assessment of the tourist product, as well as for the analysis of the structure of recreational activities and its participation in market relations.

Particular attention deserves a relatively new concept of «destinations», which represent a generalized characteristic of tourist resources, including tourist regions, their natural and geographical features, attractions, tourist routes, tourist infrastructure and tourism industry in general. In the scheme (Fig. 2 ), all the components of tourism activity (called the tourist industry) are allocated (dotted).

Conclusions. The given structure of recreational economy makes it possible to consider tourism as a branch of economy on characteristics of its components - infrastructure, service, production of tourist goods and tourism management. In this composition, it is also called «tourist industry», which is marked with a dotted line in the scheme. It is also possible to study the recreation and tourism sector as a type of economic activity. To do this, to the given direction of the components of the tourism industry should be added massive organized rest of the population. There is an opportunity to consider tourism activity in the modern format, with an assessment of tourist resources (destinations). The scheme represents the components of recreation - mass recreation and recreation and leisure which are not yet mastered in terms of economic relations and management. The presented structure of the recreational and tourist complex makes it possible for its various system objects - subjective formalizations, which consider tourists as subjects of social relations and systems, and all other components of the economy or the tourism industry itself as its object.

According to our opinion, the representation of recreational and tourist activity as an interbranch complex offers new possibilities for forecasting its development and formation of new directions of use of recreational and tourist resources (destinations). Consideration of recreation and tourism activity of a country or region as an interbranch complex provides the most complete and detailed analysis, since it involves all components of recreation and tourism - and those that already have a certain organizational and economic status and are marked as an industry or type of activity with the relevant enterprises and institutions, and those that exist as actions of the population without official definition. 


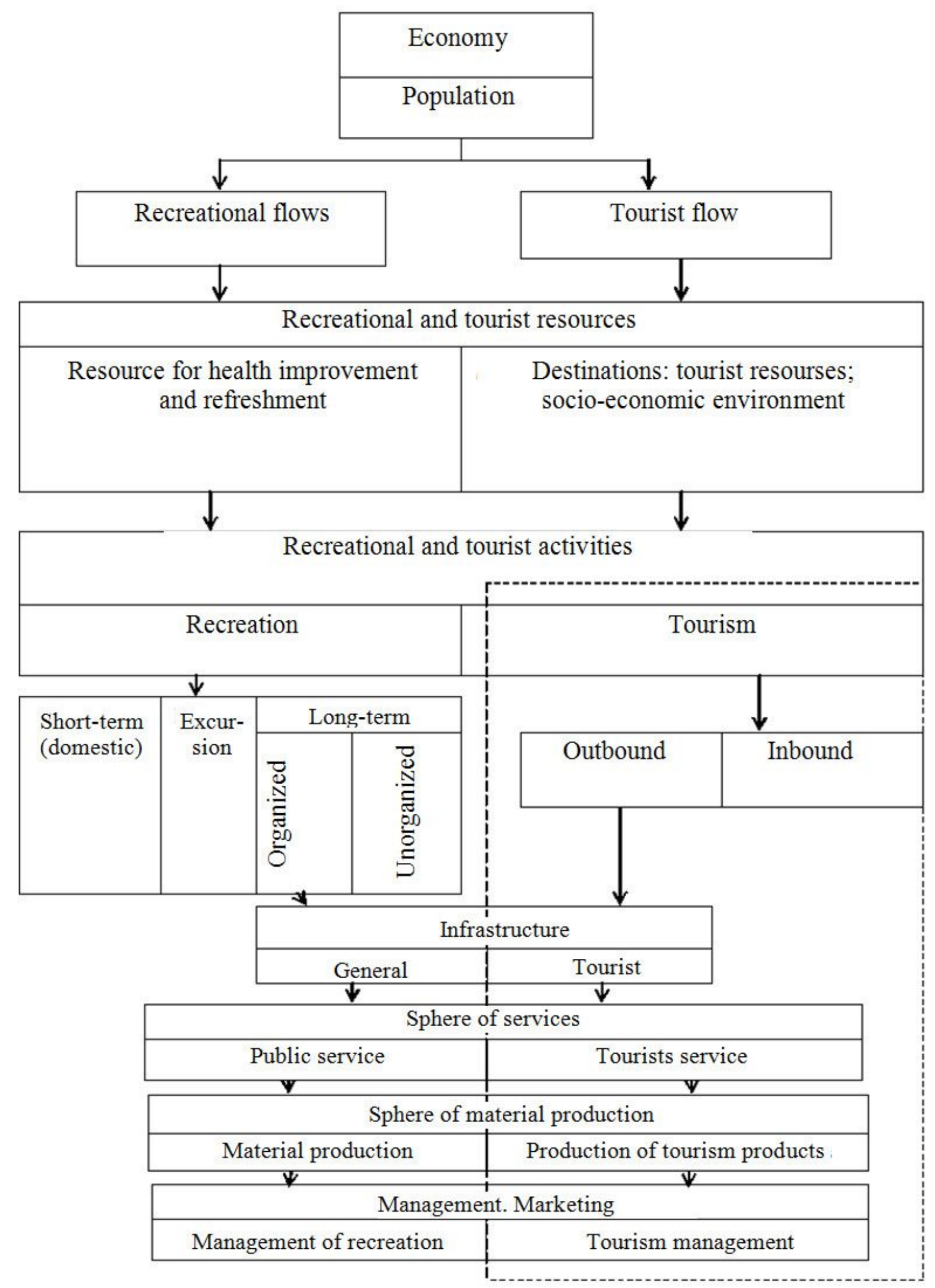

Fig.2 Structure of recreation and tourism complex by types of activity 


\section{References}

Beydyk, O. O., 2001. Rekreatsiyno - turystychni resursy Ukrayiny: metodolohiya ta metodyka analizu. Terminolohiya, rayonuvannya [Recreation tourist resources of Ukraine: methodology and methods of analysis. Terminology zoning], K.: VTs. Kyiv university, 398. (in Ukrainian).

Dyachenko, L. P., 2007. Ekonomika turystychnoho biznesu [Economics of tourism business], K.: Center navch. lit, 224. (in Ukrainian).

Fedorchenko, V. K., 2010. Turyzmolohiya (teoriya turyzmu) [Tourismology (tourism theory)], K: KUTEP, 70. (in Ukrainian).

Fomenko, N. V., 2007. Rekreatsiyni resursy ta kurortolohiya. [Recreational resources and balneology], K.: Center navch. literature, 312. (in Ukrainian).

Franzhialli, F., 2002. Tendencii' rozvytku mizhnarodnogo turyzmu [Trends in the development of international tourism] - K.: KUTEP, 25.

Leiper, N., 1979. The framework of tourism, Annals of Tourism Research, No. 6, pp. 390-407.

Lyubitseva, O. O., Pankova, Ye. V., Stafiychuk, V. I., 2007. Turystychni resursy Ukrayiny. [Tourist Resources of Ukraine], K.: Alterpres, 372. (in Ukrainian).

Maslyak, P. O., 2008. Rekreatsiyna heohrafiya [Recreational geography], K: Znannya, 343. (in Ukrainian).

Oliynyk, Ya. B., Stepanenko, A. V., 2005. Teoretychni osnovy turyzmolohiyi. [Theoretical Foundations tourismology], K.: Nika - Center, 316. (in Ukrainian).

Pazenok, V. S., Fedorchenko, V. K., 2004. Filosofiya turyzmu [Travel Philosophy], K.: Kondor, 268. (in Ukrainian).

The Travel \& Tourism Competitiveness Report, 2017. World Economic Forum, 519.

Tkachenko, T. H., 2009. Stalyy rozvytok turyzmu: teoriya,metodolohiya, realiyi biznesu [Sustainable tourism development: theory, methodology, business realities], K.: Nat. trade ekon. university, 463. (in Ukrainian).

Topchiyev, O. H., 2005. Rekreatsiyno - heohrafichni doslidzhenny V rozdil. [Recreation-geographical research (chapter XIV)], Suspil'no heohrafichni doslidzhennya: metodolohiya, metody, metodyky [Socio - geographic research, methodology, methods, techniques], Odesa: Astroprynt, 632. (in Ukrainian).

Van Tsynshen, 2003. Osnovy territorial'noj organizacii rekreacionnoj geografii [Fundamentals of the territorial organization of recreational geography], Odessa: Astroprynt, 124. (in Russian).

Velychko, V. V., 2013. Orhanizatsiya rekreatsiynykh posluh. [Organisation recreational services], Kharkiv: KhNUMH. (in Ukrainian).

Zoryn, Y. V., Kvartal'nov, V. A., 2000. Enciklopediya turizma: spravochnik [Tourism Encyclopedia: Directory], M.: Finances and statistics, 368. (in Russian). 